\title{
Distribution patterns and foraging ground productivity determine clutch size in Mediterranean loggerhead turtles
}

\author{
Luis Cardona ${ }^{1}$, Marcel Clusa ${ }^{1, *}$, Elena Eder ${ }^{1,2}$, Andreas Demetropoulos ${ }^{3}$, \\ Dimitris Margaritoulis ${ }^{4}$, ALan F. Rees ${ }^{4}$, Abdulmaula A. Hamza ${ }^{5}$, Mona Khalil ${ }^{6}$, \\ Yaniv Levy ${ }^{7}$, Oguz Türkozan $^{8}$, Isabel Marín ${ }^{1}$, Alex Aguilar ${ }^{1}$ \\ ${ }^{1}$ Department of Animal Biology and IRBio, University of Barcelona, Av. Diagonal 643, 08028 Barcelona, Spain \\ ${ }^{2}$ Centro Nacional Patagónico (CENPAT-CONICET), 9210 Puerto Madryn Chubut, Argentina \\ ${ }^{3}$ Cyprus Wildlife Society, Emmanuel Xanthou 11, PO Box 24281, 1703 Nicosia, Cyprus \\ ${ }^{4}$ ARCHELON, The Sea Turtle Protection Society of Greece, Solomou 57, 10432 Athens, Greece \\ ${ }^{5}$ Libyan Seaturtle Program, Environment General Authority, Alfateh University, PO Box 13793, Tripoli, Libya \\ ${ }^{6}$ MEDASSET, PO Box 19, Tyre, Lebanon \\ ${ }^{7}$ The Israel Sea Turtle Rescue Centre, Nature Parks Authority, Mevoot Yam, Mikhmoret 40297, Israel \\ ${ }^{8}$ Adnan Menderes University, Faculty of Science and Arts, Department of Biology, Aydin, Turkey
}

\begin{abstract}
Loggerhead turtles Caretta caretta use a wide variety of foraging strategies, and some populations forage in sub-optimal habitats. Different foraging strategies may not be equivalent in terms of fitness and may result in differences in adult body size and clutch size among populations. Accordingly, we tested whether differences in clutch size among rookeries in the Mediterranean Sea are related to differential use of foraging grounds of contrasting productivity. Stable isotope ratios of carbon and nitrogen of turtle hatchlings from 8 Mediterranean rookeries were used to characterise the foraging grounds of their mothers. Clutch size was also studied in each rookery to assess reproductive output linked to foraging ground productivity. According to stable isotope ratios, most of the females nesting in the considered rookeries foraged in the southern Ionian Sea. The highly productive Adriatic/northern Ionian Sea region was mainly used by females nesting in western Greece. The explanation for these patterns might be linked to water circulation patterns and drifting trajectories followed during developmental migrations, which might determine individual knowledge on the location of productive foraging patches. Average clutch size in each rookery was positively correlated to the proportion of females accessing highly productive areas such as the Adriatic/northern Ionian Sea. This has a strong influence on reproductive output, and hence females using the most productive foraging grounds had the largest clutch sizes.
\end{abstract}

KEY WORDS: Caretta caretta $\cdot$ Currents $\cdot$ Foraging ground $\cdot$ Primary productivity $\cdot$ Reproductive output $\cdot$ Rookery $\cdot$ Stable isotopes

Resale or republication not permitted without written consent of the publisher

\section{INTRODUCTION}

Habitat quality has a strong influence on survival, fitness and reproductive output in animal species (Halama \& Reznick 2001). Free distribution models assume that wild animals exploiting heterogeneous habitats select the most suitable foraging patches based on knowledge of habitat heterogeneity (Stephens \& Krebs 1986). However, several wild populations have been recorded foraging in areas that 
offer lower profitability and reproductive output; i.e. sub-optimal (Pyke 1984). This might have an effect on populations, as different foraging strategies may not be equivalent in terms of fitness and may result in differences in adult body size or clutch size among populations (Broderick et al. 2003).

The use of sub-optimal foraging strategies has been recorded in certain populations of large marine vertebrate species such as the South American sea lion Otaria flavescens (Drago et al. 2010), the leatherback turtle Dermochelys coriacea (Shillinger et al. 2008) and the loggerhead turtle Caretta caretta (Zbinden et al. 2011, Eder et al. 2012). The loggerhead turtle is the most abundant sea turtle in subtropical and warm temperate regions of the world and has a complex life cycle characterised by long migrations (Bolten 2003, Plotkin 2003). During juvenile stages, loggerhead turtles undertake developmental migrations in which they disperse thousands of kilometres across the ocean to recruit to adult foraging grounds (Bolten 2003). These juvenile migrations may involve frequent shifts in habitat (McClellan \& Read 2007, Casale et al. 2008, Cardona et al. 2009, Mansfield et al. 2009, McClellan et al. 2010) but, after settlement, adult turtles remain faithful to the same foraging ground throughout most of their life (Broderick et al. 2007, Schofield et al. 2010, Vander Zanden et al. 2010, Hawkes et al. 2011).

However, although adult individual turtles show strong fidelity to foraging grounds and strong philopatry to nesting areas, several authors have suggested that adults nesting in a same rookery may present a wide variety of foraging strategies and destinations (Hatase et al. 2002, Hawkes et al. 2006, 2011, Mansfield et al. 2009, Reich et al. 2010, Vander Zanden et al. 2010, Zbinden et al. 2011, Arendt et al. 2012, Ceriani et al. 2012, Eder et al. 2012, Pajuelo et al. 2012). This variety might arise from individual differences in the knowledge on heterogeneity of habitats (Hatase et al. 2002, Hays et al. 2010, Eder et al. 2012). Because different drifting trajectories are followed during developmental migrations (Wyneken et al. 2008, Hays et al. 2010, Putman et al. 2012), the habitat patches visited by individuals from the same rookery might stochastically differ (McClellan \& Read 2007, McClellan et al. 2010). These differences may influence decisions at the time of recruitment; the most productive habitat patches visited during juvenile stages may be those chosen as adult foraging grounds, as also

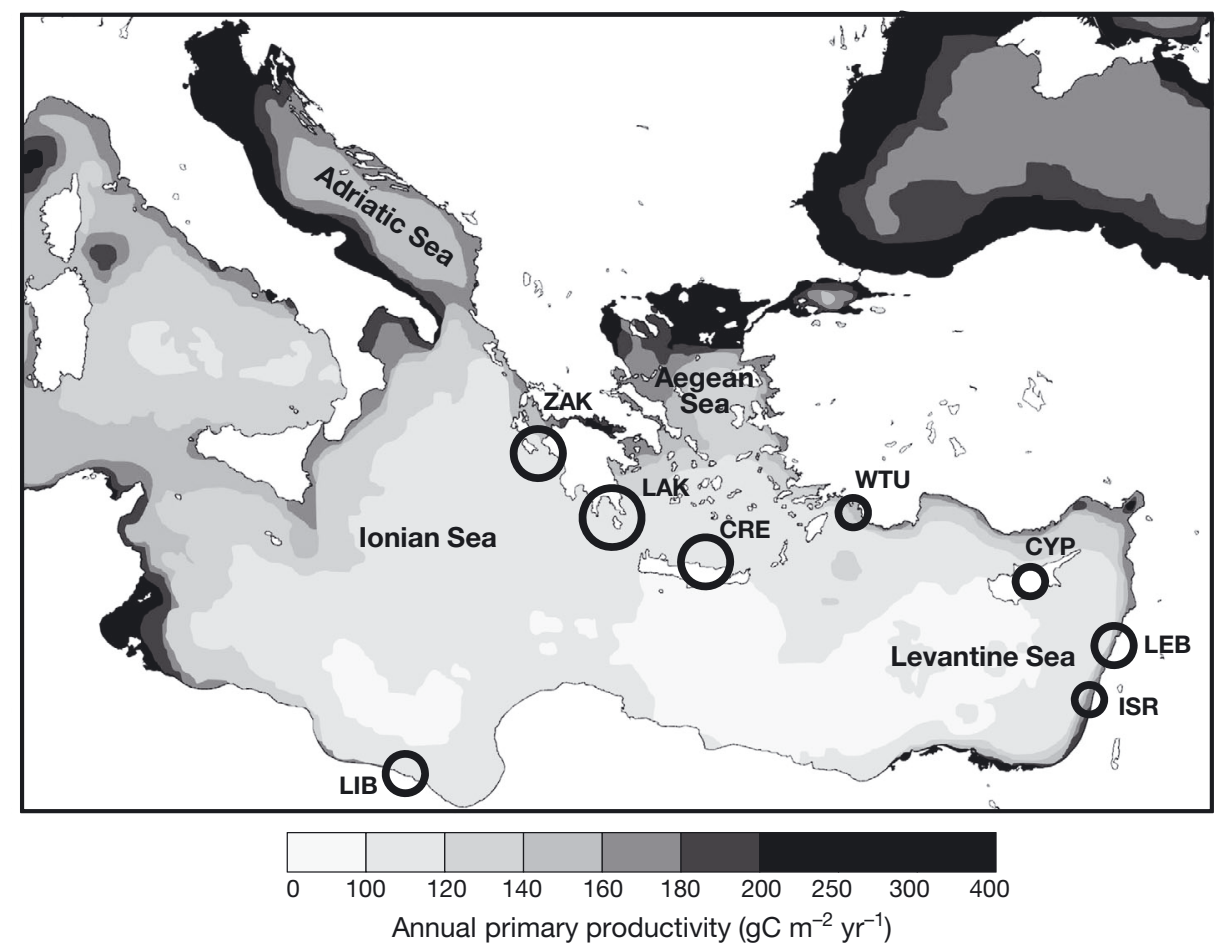

Fig. 1. Sampled rookeries of the loggerhead turtle in the Mediterranean Sea. Circles represented to scale reflecting mean clutch size per rookery (see Table 1). Annual primary production $\left(\mathrm{gC} \mathrm{m}^{-2} \mathrm{yr}^{-1}\right)$ over the period 1997 to 2001 adapted and modified from Bosc et al. (2004). LIB (Libya), ISR (Israel), LEB (Lebanon), CYP (Cyprus), WTU (western Turkey), CRE (Crete), LAK (Lakonikos), ZAK (Zakynthos) 
seen in the leatherback turtle (Fossette et al. 2010, Gaspar et al. 2012).

Productive habitat patches in the Mediterranean Sea are scarce and scattered throughout the basin (Fig. 1). According to the optimal foraging theory (Stephens \& Krebs 1986), most of the females nesting in the Mediterranean Sea would be expected to forage in the highly productive Adriatic Sea to maximise reproductive output. However, recent studies have shown many cases departing from this principle. The scant data available from studies based on satellite tracking and passive tag recovery of females indicate that only a very small proportion of turtles nesting in Libya (Hochscheid et al. 2012), Crete (Margaritoulis \& Rees 2011, Patel et al. 2012) and Cyprus (Broderick et al. 2007) and only half of the females nesting in western Greece (Margaritoulis et al. 2003, Hays et al. 2010, Zbinden et al. 2011) forage in the Adriatic Sea. The explanation probably lies in the complex pattern of surface circulation in the eastern Mediterranean Sea (Hamad et al. 2006, Hays et al. 2010) which likely hinders access of juveniles from most rookeries in the eastern Mediterranean Sea to the productive waters of the Adriatic Sea, with juveniles from western Greece being the only exception (Hays et al. 2010). Thus, if adult foraging grounds are selected on the basis of knowledge gained during the developmental migration (Hatase et al. 2002, Hays et al. 2010, Eder et al. 2012, Gaspar et al. 2012), only females from rookeries in western Greece would be expected to settle into the Adriatic Sea.

Access to the Adriatic Sea by turtles from western Greece is likely to promote their fitness and may explain why turtles nesting there are larger and lay more eggs than anywhere else in the Mediterranean Sea (Margaritoulis et al. 2003). If this were the case, it would demonstrate that the above mentioned variety of foraging strategies may not be equivalent in terms of fitness (Hatase et al. 2002, Reich et al. 2010, Zbinden et al. 2011, Eder et al. 2012). Accordingly, this paper aims to investigate whether differences in clutch size among rookeries in the eastern Mediterranean Sea are a consequence of differential use by adult females of foraging grounds of contrasting productivity. To do so, we compare the mean clutch size in 8 major rookeries with the proportion of females from each rookery that forage in highly productive habitat patches, as characterised by stable isotopes of carbon and nitrogen.
Previous research on sea turtles has demonstrated that stable isotope ratios in females and hatchlings are highly correlated (Frankel et al. 2012). Accordingly, stable isotope ratios in eggs and hatchlings offer a good alternative to reconstruct the foraging habitats of females without disturbing them during the nesting process.

\section{MATERIALS AND METHODS}

\section{Sampling}

Samples of muscle were taken from 152 dead hatchlings from a selection of rookeries in the Mediterranean Sea (Fig. 1, Table 1). Nest sampling (2003 to 2006) included central Libya (west of Sirte), Israel (scattered sites along the whole coastline), Lebanon (El Mansouri), Cyprus (Alagadi and Akamas), western Turkey (Fethiye) and Greece (Rethymno on the Island of Crete, Lakonikos Bay and Zakynthos). Nests were excavated after hatchling emergence, and samples were collected from 1 fresh-dead hatchling per nestr. Only 1 hatchling per nest was analysed because little variation had been previously found among individuals from a given nest (Frankel et al. 2012). Through this methodology, no hatchling was sacrificed for this experiment. No differences in stable isotope composition between live and freshdead hatchlings were expected, as decomposition was not obvious and even if so, Payo-Payo et al. (2013) found that stable isotope ratios in the muscle of loggerhead turtles do not change over time due to decomposition. Samples were stored in $95 \%$ ethanol, known not to modify stable isotope ratios of muscle tissue (Hobson et al. 1997).

Table 1. Caretta caretta. Mean stable isotope ratios of hatchling muscle $(\%)$ and mean and range clutch sizes (number of eggs) of nests with at least 1 dead hatchling from the major loggerhead rookeries in the Mediterranean Sea. Number of analysed individuals (n) and standard deviations $( \pm$ ) included. LIB (Libya), ISR (Israel), LEB (Lebanon), CYP (Cyprus), WTU (western Turkey), CRE (Crete), LAK (Lakonikos), ZAK (Zakynthos)

\begin{tabular}{|c|c|c|c|c|c|}
\hline \multirow[t]{2}{*}{ Rookeries } & \multirow[t]{2}{*}{$\mathrm{n}$} & \multicolumn{2}{|c|}{ Stable isotope ratios } & \multicolumn{2}{|c|}{ Clutch size } \\
\hline & & $\delta^{15} \mathrm{~N}$ & $\delta^{13} \mathrm{C}$ & Mean & Range \\
\hline LIB & 25 & $9.8 \pm 0.9$ & $-16.5 \pm 1.8$ & $91.1 \pm 14.3$ & $81-101$ \\
\hline ISR & 18 & $9.3 \pm 1.9$ & $-17.0 \pm 1.8$ & $78.4 \pm 22.9$ & $35-123$ \\
\hline LEB & 18 & $9.9 \pm 1.3$ & $-16.2 \pm 1.9$ & $91.5 \pm 51.6$ & $57-122$ \\
\hline CYP & 27 & $9.9 \pm 2.3$ & $-16.4 \pm 2.0$ & $79.0 \pm 16.9$ & $38-113$ \\
\hline WTU & 18 & $10.1 \pm 2.1$ & $-15.1 \pm 2.2$ & $80.5 \pm 37.5$ & $55-105$ \\
\hline CRE & 14 & $9.6 \pm 1.5$ & $-16.1 \pm 2.0$ & $102.0 \pm 25.2$ & $52-149$ \\
\hline LAK & 13 & $10.7 \pm 2.4$ & $-16.2 \pm 1.9$ & $129.1 \pm 24.9$ & $99-171$ \\
\hline ZAK & 20 & $11.4 \pm 2.3$ & $-16.7 \pm 1.6$ & $111.8 \pm 21.9$ & $71-136$ \\
\hline
\end{tabular}


Independency between samples can be assumed as sampling protocol was designed to avoid pseudoreplication: i.e. female flipper tagging and samples were taken from clutches laid within a $15 \mathrm{~d}$ window to avoid sampling hatchlings from the same individual turtle, as females rarely nest at intervals shorter than this period (Dutton 1995). Clutch size was calculated from the excavated nests remains, including both unhatched eggs and empty egg shells.

\section{Stable isotope analysis}

The analysis of stable isotope signatures in animal tissues provides information on diet but also can be used to track foraging ground locations, as tissue signatures reflect those of the specific food webs present in a certain area (Hobson 1999, Fry 2006).

Although the isotopic landscape, or isoscape, of the central and eastern Mediterranean Sea is poorly known, Zbinden et al. (2011) reported differences between the average $\delta^{15} \mathrm{~N}$ values in female turtles foraging in the Adriatic/northern Ionian Sea and in those foraging in the southern Ionian Sea. To gain a

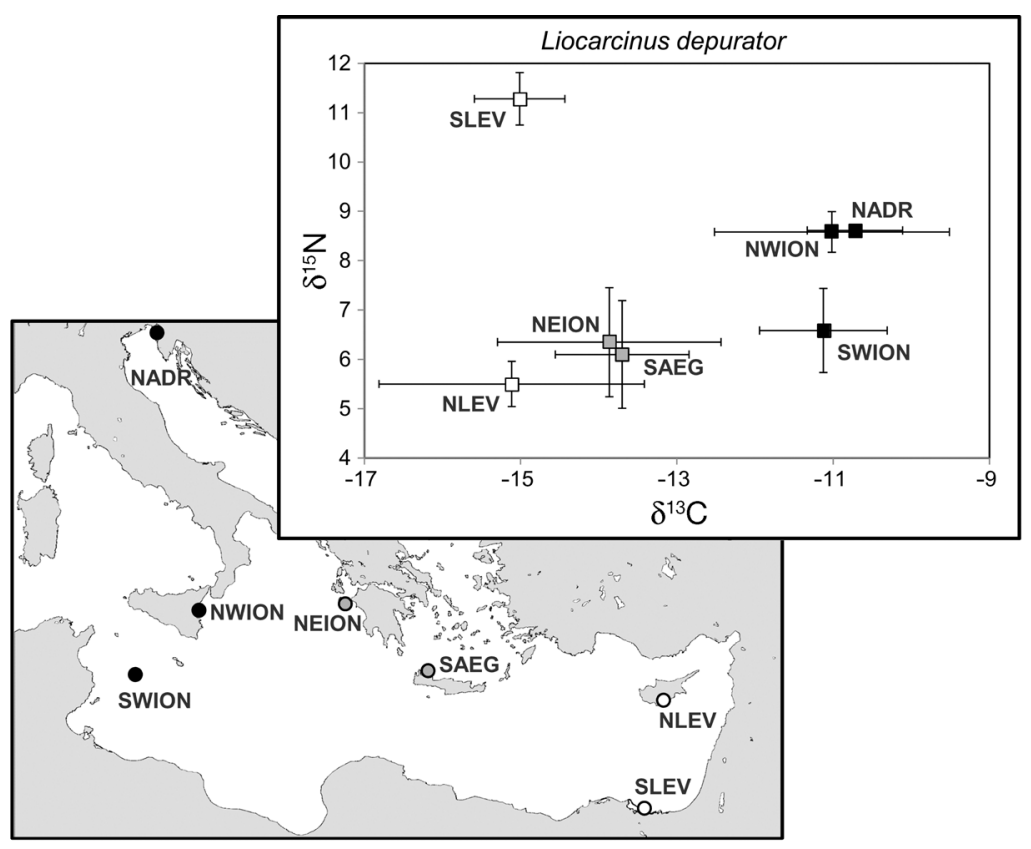

Fig. 2. Liocarcinus depurator. Sampling locations and stable isotope ratios (\%) from 7 different areas of the Mediterranean Sea: SLEV (southern Levantine Sea), NLEV (northern Levantine Sea), SAEG (southern Aegean Sea), NEION (north-eastern Ionian Sea), NADR (northern Adriatic Sea), NWION (north-western Ionian Sea), SWION (south-western Ionian Sea). Standard deviation bars included. Graded colour scale reflects position of the sampled areas within the Mediterranean Sea from westernmost (black) to easternmost areas (white) further insight into the spatial variation in isotopic ratios we collected samples of the benthic crab Liocarcinus depurator, a widespread species that constitutes a major component in the diet of adult loggerhead turtles (Tomás et al. 2001, Casale et al. 2008, Travaglini \& Bentivegna 2011). A sample of 5 benthic crabs was collected in each of 7 locations spread over the central and eastern Mediterranean Sea (Fig. 2): Port Said (southern Levantine Sea), Limassol (northern Levantine Sea), Chania (southern Aegean Sea), Zakynthos (north-eastern Ionian Sea), Trieste (north Adriatic Sea), Catania (north-western Ionian Sea) and Lampedusa (south-western Ionian Sea).

Muscle tissue samples from crabs and hatchlings were oven-dried at $60^{\circ} \mathrm{C}$ for 48 to $72 \mathrm{~h}$ and then ground into fine powder. Lipids were extracted from all tissues with a chloroform-methanol (2:1) solution. Approximately $0.3 \mathrm{mg}$ of powdered sample were weighed into tin cups, combusted at $1000^{\circ} \mathrm{C}$, and analysed in a continuous flow isotope ratio mass spectrometer (Flash 112 IRMS Delta C Series EA Thermo Finningan) at the Scientific and Technological Centre of the University of Barcelona. Stable isotope ratios were expressed in parts per thousand (\%o) according to the equation $\delta X=\left[\left(R_{\text {sample }} /\right.\right.$ $R_{\text {standard }}$ ) - 1] $\times 1000$, where $X$ is ${ }^{13} \mathrm{C}$ or ${ }^{15} \mathrm{~N}$ and $R$ is the corresponding ratio of the heavier to the lighter isotope (i.e. ${ }^{13} \mathrm{C} /{ }^{12} \mathrm{C}$ or $\left.{ }^{15} \mathrm{~N} /{ }^{14} \mathrm{~N}\right)$. International isotope standards of known ${ }^{13} \mathrm{C} /{ }^{12} \mathrm{C}$ and ${ }^{15} \mathrm{~N} /{ }^{14} \mathrm{~N}$ ratios were used to a precision of $0.2 \%$ : IAEA CH6 $\left(\delta^{13} \mathrm{C}=-10.3 \%\right)$, USGS $40\left(\delta^{13} \mathrm{C}=\right.$ $-25.8 \%$ ) and IAEA CH7 $\left(\delta^{13} \mathrm{C}=-31.6 \%\right.$ ) for carbon and USGS $40\left(\delta^{15} \mathrm{~N}=-4.3 \%\right)$, IAEA N1 $\left(\delta^{15} \mathrm{~N}=0.8 \%\right.$ ), IAEA $600\left(\delta^{15} \mathrm{~N}=\right.$ $1.0 \%$ ) and IAEA $\mathrm{N} 2\left(\delta^{15} \mathrm{~N}=20.4 \%\right)$ for nitrogen.

\section{Data analysis}

Differences in the isotope composition among populations of Liocarcinus depurator and loggerhead hatchlings were assessed independently for carbon and nitrogen through ANOVA tests with SPSS v15.0.

Zbinden et al. (2011) analysed egg yolk; in this paper we analyse muscle from hatchlings. To our knowledge, studies have not focused on the isotopic correlation and discrimination factors between egg yolk and muscle of hatchlings, al- 
though the relative abundance of the heavy isotopes is expected to increase during embryonic development due to the preferential excretion of light isotopes as a result of animal metabolism (Martínez del Rio et al. 2009). To assess the relevance of such a potential source of bias, the stable isotope ratios provided by Zbinden et al. (2011) for egg yolk from females nesting in Zakynthos were compared with the stable isotope ratios of hatchlings for the same beach (see below), using a Student's $t$-test with SPSS v15.0. As differences were not statistically significant (see 'Results'), the values from Zbinden et al. (2011) were considered good proxies to classify the foraging ground of the females whose hatchlings were analysed in the present study. Individuals that fell in the overlapping range between the Adriatic/northern Ionian Sea and the southern Ionian Sea were assigned to the area with the closest values for subsequent calculations. Values of $\delta^{15} \mathrm{~N}$ or $\delta^{13} \mathrm{C}$ beyond the range reported by Zbinden et al. (2011) were considered to reveal foraging in other areas, and hatchlings were classified accordingly. A Pearson's correlation test carried out with SPSS v15.0 was used to assess the relation between the proportion of hatchlings from females foraging in the Adriatic/northern Ionian Sea in each rookery and the distance to that region. The test was performed twice with minimum linear and coastal distances to test for possible differences.

The relationship between reproductive output and putative foraging ground was assessed by comparing the average clutch size of nests likely to have been laid by mothers foraging in the Adriatic/northern Ionian Sea $\left(\delta^{15} \mathrm{~N}>11.5 \%\right.$, according to Zbinden et al. 2011) with those with hatchlings presenting a value of $\delta^{15} \mathrm{~N}$ lower than $11 \%$ thus likely to have been laid by mothers foraging in the southern Ionian Sea. A Student's $t$-test was performed to analyse the statistical significance of such difference.

A data set of 158 nests from Israel was used to assess whether the protocol used here resulted in any bias in clutch size estimation. A Student's $t$-test was used to compare the average clutch size of nests with at least 1 dead hatchling and those without any dead hatchlings.

\section{RESULTS}

\section{Stable isotope analysis}

The $\delta^{13} \mathrm{C}$ ratios of Liocarcinus depurator varied significantly among sampling locations $\left(F_{6,28}=14.041\right.$, $\mathrm{p}<0.001$ ) and revealed a longitudinal gradient along the eastern Mediterranean Sea, with the highest values in the Adriatic Sea and the western Ionian Sea and the lowest values in the Levantine Sea (Fig. 2). Differences in the $\delta^{15} \mathrm{~N}$ values of $L$. depurator were also statistically significant among sampling locations $\left(F_{6,28}=37.938, \mathrm{p}<0.001\right)$, with the highest values in the southern Levantine, the Adriatic and the north-western Ionian seas and the lowest values in the northern Levantine Sea.

Values of $\delta^{15} \mathrm{~N}$ (Table 1) for turtle hatchlings were significantly different among rookeries $\left(F_{7,145}=1.553\right.$, $\mathrm{p}=0.037)$, although no significant differences were detected for $\delta^{13} \mathrm{C}$ values $\left(F_{7,145}=9.092, \mathrm{p}=0.151\right)$. The post-hoc Tukey test revealed significant differences of $\delta^{15} \mathrm{~N}$ values only between Zakynthos and Israel.

Differences between the stable isotope ratios reported by Zbinden et al. (2011) for egg yolk from Zakynthos and the corresponding ratios here reported for hatchling muscle from the same beach were not statistically significant, either for $\delta^{15} \mathrm{~N}$ $\left(\right.$ yolk $=11.0 \pm 2.3 ;$ muscle $=11.4 \pm 2.3 ; t_{30}=0.436, \mathrm{p}=$ $0.666)$ or $\delta^{13} \mathrm{C}$ (yolk $=-17.7 \pm 1.6$; muscle $=-16.7 \pm$ $\left.1.6 ; t_{30}=1.717, \mathrm{p}=0.096\right)$. Accordingly, the stable isotope ratios reported by Zbinden et al. (2011) were used as a benchmark to identify the foraging grounds of the females laying the nests considered here.

When considered individually, 106 hatchlings fell within the range of $\delta^{15} \mathrm{~N}$ values previously reported for the eggs from females foraging in the southern Ionian Sea, 21 within the range of $\delta^{15} \mathrm{~N}$ values corresponding to foraging in the Adriatic/northern Ionian Sea and 20 hatchlings to the range in between the 2 areas (Fig. 3). The $\delta^{15} \mathrm{~N}$ values of the remaining 5 hatchlings fell outside that range and their mothers likely foraged in other areas. Although females foraging in the Adriatic/northern Ionian Sea and in the southern Ionian Sea were not expected to differ in $\delta^{13} \mathrm{C}$ values, 17 hatchlings fell beyond the $\delta^{13} \mathrm{C}$ range values reported for both areas, thus indicating the use of other foraging grounds (Fig. 4). According to the isoscape revealed by Liocarcinus depurator, the 2 hatchling samples from Israel, characterised by very low $\delta^{13} \mathrm{C}$ values, could correspond to females foraging in the Levantine Sea. The remaining 15 hatchlings were too enriched in ${ }^{13} \mathrm{C}$ to correspond to females using the Ionian Sea or the Adriatic Sea according to the values provided by Zbinden et al. (2011) and, according to the eastward decrease in $\delta^{13} \mathrm{C}$ revealed by the $L$. depurator isoscape, they might have foraged somewhere to the west.

The proportion of females foraging in the Adriatic/ northern Ionian Sea increased downstream the main 

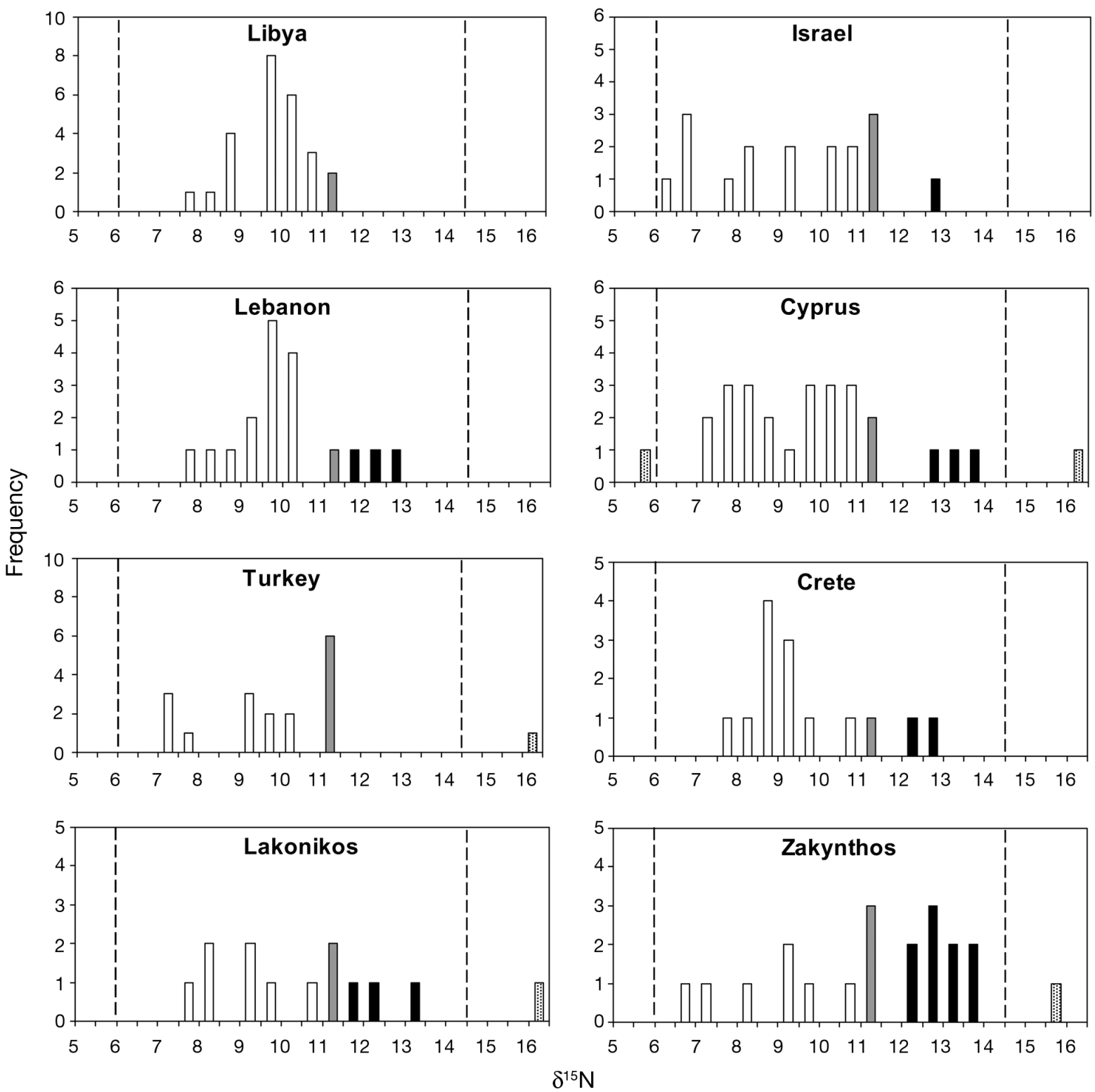

Fig. 3. Caretta caretta. Individual $\delta^{15} \mathrm{~N}$ values (\%) from loggerhead hatchlings sampled in the studied rookeries. Dashed lines show the range reported by Zbinden et al. (2011) for the Ionian Sea and the Adriatic Sea combined. White bars denote hatchlings from females likely to have foraged in the southern Ionian Sea, black bars denote hatchlings from females likely to have foraged in the Adriatic/northern Ionian Sea and grey bars show hatchlings with intermediate values. The dotted bars represent hatchlings corresponding to females foraging somewhere else

current, from $4 \%$ in Libya to $45 \%$ in Zakynthos (Fig. 5). A significant correlation was observed between the shortest geographical distance (Lat/Long distance) from each rookery to the Adriatic Sea and the proportion of females foraging in the Adriatic/ northern Ionian Sea (Pearson's correlation test, $\mathrm{r}=$ $-0.769, p=0.026)$. When the distance from the beach to the Adriatic Sea was computed along the coastline (coastal distance) the correlation was still significant (Pearson's correlation test, $\mathrm{r}=-0.784, \mathrm{p}=0.021$ ).

\section{Clutch size}

The average clutch size per rookery ranged from 78 to 129 eggs per nest, and the individual clutch size from 35 to 171 eggs (Table 1). These recordings correspond to the average clutch size of nests with at least 1 dead hatchling, which is slightly larger than the average clutch size of nests without dead hatchlings in the data set from Israel used as reference (clutch size no dead $=70.5 \pm 20.7$ eggs; 

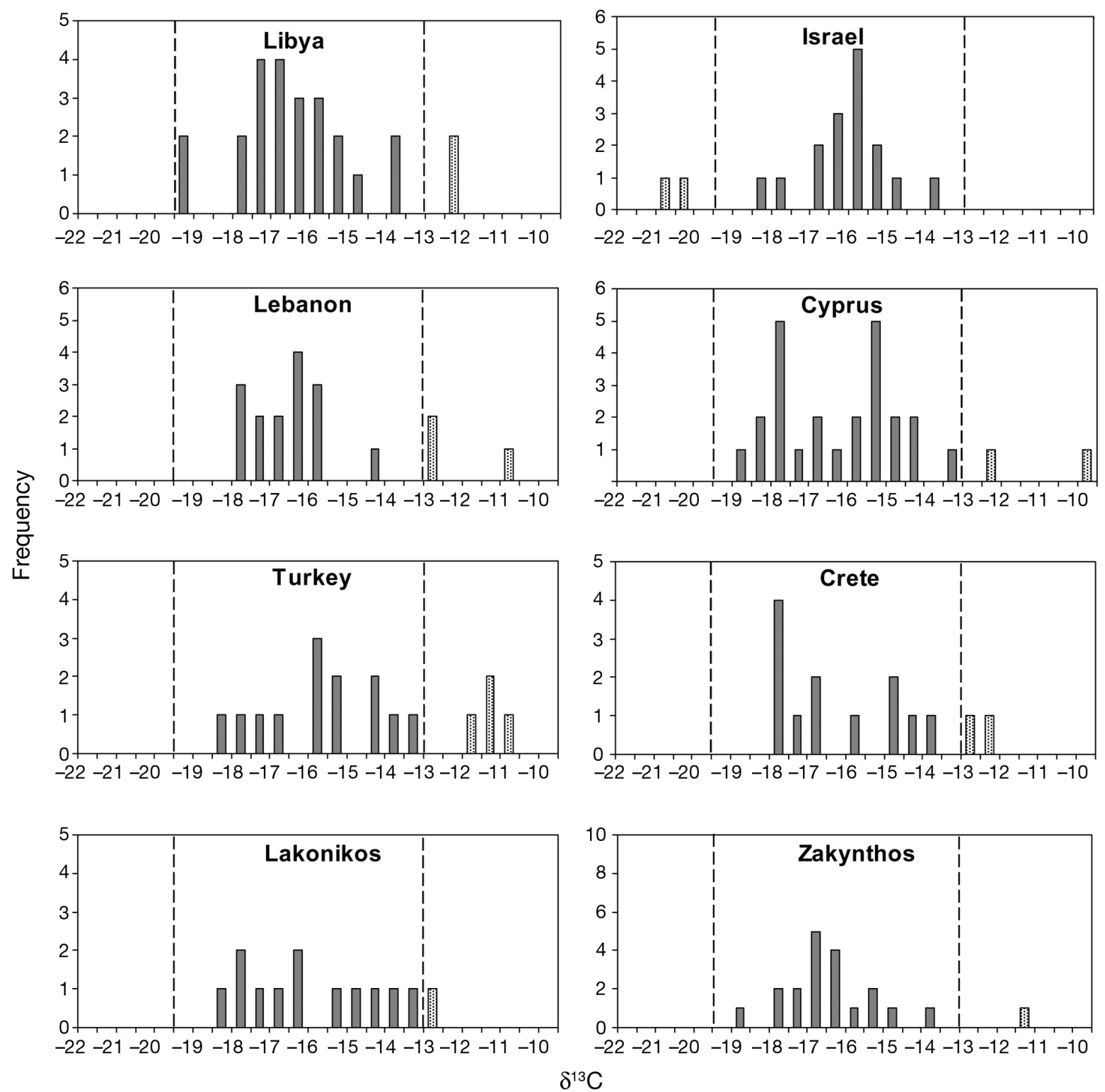

Fig. 4. Caretta caretta. Individual $\delta^{13} \mathrm{C}$ values (\%) from loggerhead hatchlings sampled in the studied rookeries. Dashed lines show the range reported by Zbinden et al. (2011) for the Ionian Sea and the Adriatic Sea combined. Grey bars denote hatchlings from females likely to have foraged either in the Ionian Sea or the Adriatic Sea and dotted bars denote hatchlings corresponding to females foraging somewhere else

clutch size $1_{\text {dead }}=78.1 \pm 24.9$ eggs $; t_{151}=2.069, \mathrm{p}=$ 0.040).

Clutch size was significantly larger when the $\delta^{15} \mathrm{~N}$ values of the hatchlings was $>11.5 \%$ o (mean clutch size $=104.6 \pm 29.2$ eggs, $\mathrm{n}=40$ ) than when the $\delta^{15} \mathrm{~N}$ values of the hatchlings was $<11 \%$ (mean clutch size $=89.4 \pm 29.1$ eggs; $\mathrm{n}=74)\left(t_{112}=2.229, \mathrm{p}=0.028\right)$. Accordingly, the 2 rookeries with the highest proportion of females likely to forage in the Adriatic/northern Ionian Sea (Zakynthos and Lakonikos) had the largest average clutch size (Fig. 1, Table 1).

\section{DISCUSSION}

The stable isotope results reported here identify the southern Ionian Sea as the major foraging ground for most of the rookeries analysed, and indicate that the Adriatic/northern Ionian Sea region is used by a high proportion of females nesting in western Greece. This is supported by the reconstruction of the regional isoscape through values obtained for Liocarcinus depurator, which revealed a previously undescribed decline in the $\delta^{13} \mathrm{C}$ values in the Mediterranean Sea 


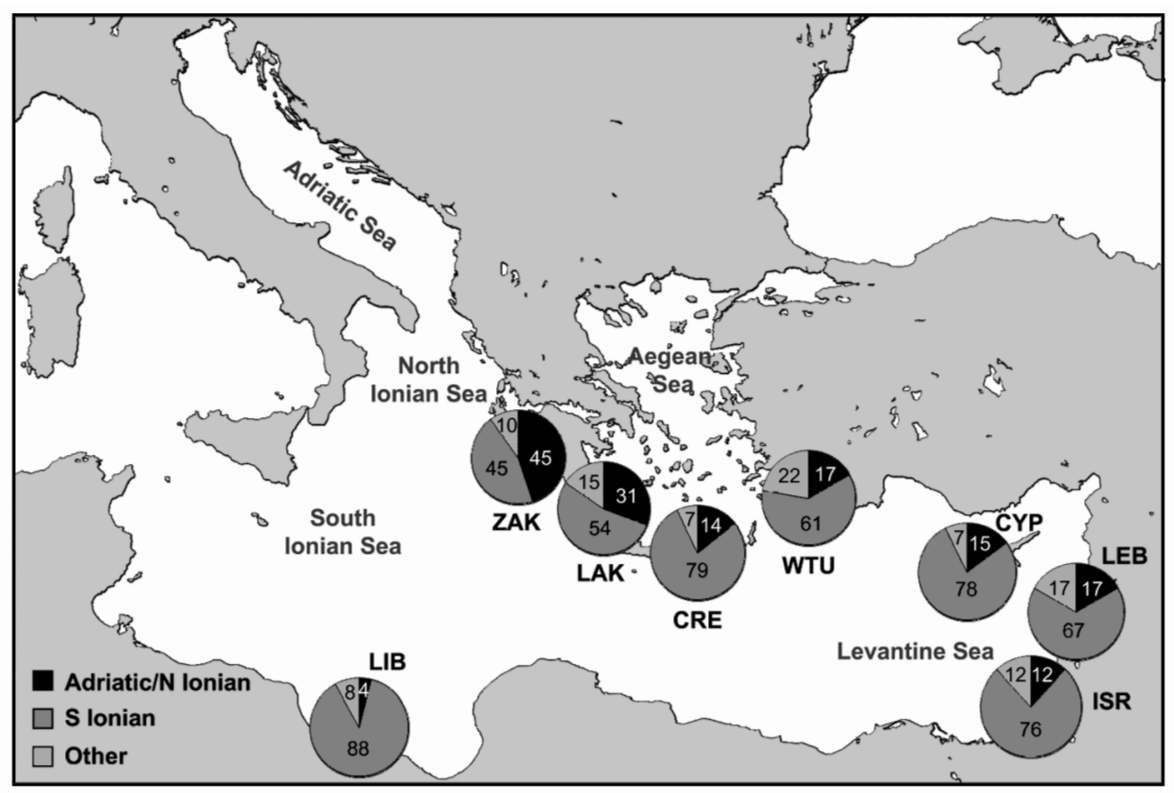

Fig. 5. Caretta caretta. Proportion of nesting females potentially foraging in each of the 3 different areas, as derived from stable isotope analyses. Percentages included in the pies

moving from west to east. This pattern is probably caused by the decline of planktonic primary productivity from west to east in the region (Bosc et al. 2004, our Fig. 1) and hence reflects a decreasing reliance of primary producers on ${ }^{13} \mathrm{C}$. On the other hand, the highest $\delta^{15} \mathrm{~N}$ values were observed in the Adriatic Sea, the north-western Ionian Sea and the southern Levantine Sea. These high $\delta^{15} \mathrm{~N}$ values observed could be the result of ${ }^{15} \mathrm{~N}$-enriched freshwater run-off (Oczkowski et al. 2009), particularly in the Adriatic Sea and north-western Ionian Sea, where its waters receive 60 to $70 \%$ of the inorganic nutrient load from the Po River discharge (Degobbis \& Gilmartin 1990, Voss et al. 2011). Contrarily, the lower $\delta^{15} \mathrm{~N}$ values found elsewhere were characteristic of Mediterranean oceanic waters (Pantoja et al. 2002).

Direct comparison between stable isotope ratios in Liocarcinus depurator and in turtles is not possible because discrimination factors are not known to accurately compare the 2 species isotopically (Vander Zanden \& Rasmussen 2001). However, the isoscape derived from $L$. depurator reflects the relative enrichment in heavy isotopes expected for turtles foraging in productive regions. The usefulness of this approach is demonstrated by the concordance between the results previously reported by Zbinden et al. (2011) on stable isotope ratios in the eggs laid in Zakynthos and the regional isoscape here obtained from $L$. depurator; as both concur in indicating that samples from the Adriatic Sea are more enriched in ${ }^{15} \mathrm{~N}$ than those from the southern Ionian Sea.

Previous studies with tagging and satellite tracking had identified the southern Ionian Sea as a main foraging ground for adult loggerhead turtles nesting in western Greece (Margaritoulis et al. 2003, Hays et al. 2010, Zbinden et al. 2011), Libya (Hochscheid et al. 2012), Crete (Margaritoulis \& Rees 2011, Patel et al. 2012) and Cyprus (Broderick et al. 2007), but nothing was known about the foraging destinations of turtles nesting in western Turkey or Israel. The isoscape derived from Liocarcinus depurator confirms the southern Ionian Sea as an isotopically distinct region, and the stable isotope ratios from turtle hatchlings confirm that the southern Ionian Sea is a major foraging ground for adult females from the studied rookeries. It should be kept in mind that the protocol used did not consider nests without dead hatchlings, which are in turn characterised by a slightly lower clutch size than those with at least 1 dead hatchling. As females foraging in the southern Ionian Sea are characterised by a smaller clutch size than those foraging in the Adriatic/northern Ionian Sea, this means that the proportion of females foraging in the southern Ionian Sea has actually been slightly underestimated in this study. In any case, the widespread utilisation of the southern Ionian Sea by adult females is hardly surprising, as the area is easily accessible following the main cyclonic current of the eastern 
Mediterranean (Fig. 6) during developmental migrations according to virtual particle tracking models (Hays et al. 2010, Putman \& Naro-Maciel 2013).

In contrast, stable isotope data indicate that the highly productive Adriatic Sea (Bosc et al. 2004) and the adjoining northern Ionian Sea are largely used by females nesting in western Greece (Zbinden et al. 2011, this study), but seldom used by females from other regions (Margaritoulis \& Rees 2011, Patel et al. 2012, Hochscheid et al. 2012, this study). We found a decreasing proportion of turtles with stable isotope ratios consistent with foraging in the Adriatic/northern Ionian Sea as we moved upstream from Zakynthos to Libya. These results are consistent with the peripheral position of the Adriatic and northern Ionian Seas within the general current system of the eastern Mediterranean Sea (Hamad et al. 2006, our Fig. 6) in contrast to the central position of the southern Ionian Sea and the results of the virtual particle tracking models (Hays et al. 2010, Putman \& NaroMaciel 2013). It should be noted, however, that some parts of the northern Ionian Sea cannot be properly differentiated from the southern Aegean Sea in the isoscape derived from Liocarcinus depurator, and that the Aegean Sea is used at least by turtles nesting in Crete according to tag recovery data (Margaritoulis \& Rees 2011). As a consequence, some of the turtles classified as foraging in the Adriatic/northern Ionian Sea might actually forage in the southern Aegean Sea. Further research is needed to clarify the origin of turtles foraging there.
The limited use of the Adriatic/northern Ionian Sea by females from rookeries other than Zakynthos and Lakonikos is intriguing because the Adriatic Sea is indeed the most productive area of the western Mediterranean Sea (Bosc et al. 2004) and females foraging there are larger (Margaritoulis et al. 2003) and lay more eggs than females foraging elsewhere (Zbinden et al. 2011, this study). If turtle distribution was only dependent on a balance between food availability and distance to rookery, turtles from western Turkey, Cyprus, Israel and Lebanon would be expected to use the Adriatic/northern Ionian Sea and the southern Ionian Sea in equal proportions as these 2 foraging grounds are equidistant from rookeries in the eastern Mediterranean Sea. However, this has only been observed in Zakynthos (western Greece), where turtles present a strong dichotomy between these 2 equidistant foraging grounds (Zbinden et al. 2011, this study). Thus, settlement at the shortest distance to their natal areas, as proposed by Bowen et al. (2005), might not be enough to explain selection of foraging grounds used by turtles nesting in the eastern Mediterranean Sea. Rather the contrary, differences in knowledge of the location of productive foraging grounds due to limited dispersal during the developmental migration could also explain why adult turtles from other rookeries do not massively use the peripheral Adriatic/northern Ionian Sea as a foraging ground. Future research should focus on hatchling and juvenile tracking to test both hypotheses, as none can be excluded with the current data.

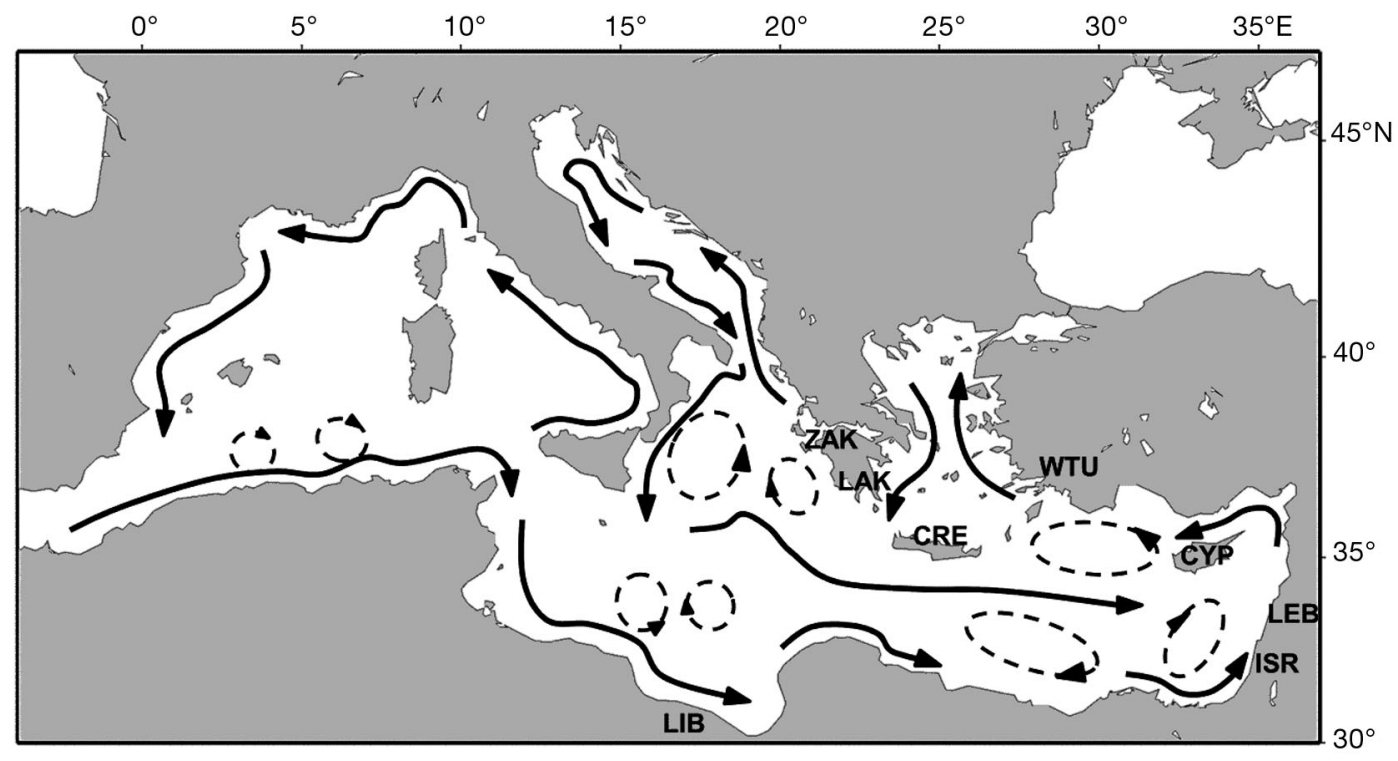

Fig. 6. Main surface circulation patterns of the Mediterranean Sea. Thin dashed lines show transient gyres and eddies. Adapted and modified after Robinson et al. (2001) and Millot \& Taupier-Letage (2004) 
Another highly productive area in the eastern Mediterranean Sea is the coastal fringe situated east of the Nile Delta, in the southern Levantine Sea (Bosc et al. 2004, Oczkowski et al. 2009). Satellite tracking has revealed the presence of females from Cyprus in the area (Broderick et al. 2007), but did not clarify whether these turtles were in transit towards the Ionian Sea because transmission ceased after the individuals reached the area. The absence of individuals simultaneously enriched in ${ }^{15} \mathrm{~N}$ and depleted in ${ }^{13} \mathrm{C}$ in comparison with those foraging in the southern Ionian Sea indicates, according to the isoscape derived from Liocarcinus depurator, limited foraging in the southern Levantine Sea-an intriguing result because this area is located downstream from the nesting beaches in Libya (Fig. 6). However, mesoscale eddies in the southern Ionian basin might retain Libyan hatchling drifters within that sub-basin (Hays et al. 2010) and hence might limit the eastward dispersal of turtle hatchlings to the Levantine Sea. This, in turn, might limit their knowledge of habitat heterogeneity and restrict adult females to use the area as a foraging ground (McClellan \& Read 2007, McClellan et al. 2010). Finally, the stable isotope ratios also showed that the northern Levantine Sea might be used as a foraging ground only by a few females from Israel, a finding in accordance with previous studies using satellite tracking (Broderick et al. 2007). This is hardly surprising, considering the low primary productivity of most of the area (Bosc et al. 2004).

The distribution patterns described here demonstrate the existence of a strong link between the foraging grounds used by adults and the location of their rookeries. This has consequences for reproductive output since we found a strong correlation between the specific foraging grounds used and the average clutch size of its nesting females. Thus, females foraging in the Adriatic/northern Ionian Sea had larger clutch sizes than females from the same rookery that forage in less productive areas such as the southern Ionian Sea. Differences between both groups may actually be even larger, since the protocol used for this study did not consider nests without dead hatchlings and hence might have slightly overestimated the average clutch size of individuals foraging in areas of low productivity.

Although female size was not assessed in this study, differences in clutch size are likely related to differences in body size (Frazer \& Richardson 1986, Miller 1997, Zbinden et al. 2011). Sea turtle females foraging in highly productive foraging grounds grow larger, improving their reproductive output and hence laying a larger number of eggs (Broderick et al. 2003, Plot et al. 2013). Accordingly, the largest clutch sizes were found in western Greece, where the largest nesting loggerhead females in the Mediterranean Sea have been recorded (Zakynthos $=82.7$ to $83.8 \mathrm{~cm}$ curved carapace length [CCL]; Lakonikos $=84.1$ to $84.6 \mathrm{~cm} \mathrm{CCL;} \mathrm{Margaritoulis} \mathrm{et} \mathrm{al.}$ 2003). In contrast, clutch size and female body size (Margaritoulis et al. 2003) were smaller in rookeries that hosted a large proportion of females foraging in the southern Ionian Sea, although turtles nesting there might present behavioural adaptations to increase fitness such as the reduced remigration interval recorded in Cyprus (Broderick et al. 2003). However, data on remigration intervals were not available for the studied beaches and hence solid conclusions on this issue could not be drawn in the current study.

Importantly, the reported results suggest that differences between rookeries are not shown at population level, but at individual level. Turtles foraging in highly productive foraging grounds nest at the same rookeries as turtles foraging in less productive grounds; those individual differences might be stochastically driven by water circulation patterns that determine the drifting trajectories followed during developmental stages (Wyneken et al. 2008, Hays et al. 2010, Putman et al. 2012), which might modulate the knowledge of productive habitat patches available in the area to be used as adult foraging grounds (McClellan \& Read 2007, McClellan et al. 2010). Actually, the populations with a larger proportion of females foraging into the highly productive habitats of the Adriatic/northern Ionian Sea are the largest in the region, whereas females foraging in the southern Ionian Sea dominate in some of the smallest populations (Casale \& Margaritoulis 2010). The Israeli and Lebanese populations are particularly interesting, as thousands of turtles were slaughtered annually during the 1920s (Sella 1982), but only a few tens of adult turtles survive currently. The regional decrease in oceanic productivity caused by the regulation of the Nile (Oczkowski et al. 2009) might have played a role in preventing the recovery of those populations, according to the results provided here.

In addition, the foraging grounds used not only can have an effect on fitness of loggerhead populations nesting the Mediterranean Sea, but also can alter their probability of survival. Bycatch rates are highly variable within the basin (Casale 2011) and the impact of fisheries interactions on foraging populations will depend on the overlap between fishing and turtle distribution (Wallace et al. 2008, 2013) and also 
on the birth rate of the populations involved. In this context, populations with a large number of individuals foraging in the southern Ionian Sea are more vulnerable to on-sea mortality than those foraging in more productive habitats. Thus, the results presented here highlight the need for further research on turtle distribution and foraging ground use to ensure survival of this species.

In summary, the observed differences in reproductive output were a result of differential use of foraging grounds of contrasting productivity. Previous research showed that access to foraging grounds in the eastern Mediterranean Sea is likely dependent on rookery location within the surface current system, which might explain the observed differences in reproductive output both at an individual and at a rookery level. This is relevant from a conservation point of view because foraging ground selection plays an important role on the species' fitness and hence, females feeding in less productive foraging grounds will have smaller clutch sizes and will therefore be more vulnerable to anthropogenic and natural threats.

Acknowledgements. We are thankful to all the researchers, assistants and volunteers who collaborated in sample collection. This study was co-funded by projects CGL2009-10017 of the Spanish Government (CICYT) and partially funded by the EU project 'Protección de Praderas de Posidonia en LICs de Baleares' LIFE00NAT/E/7303 and 'Zoo de Barcelona'. The tissue samples used in this paper were provided by the BMA tissue bank managed by the 'Fundació Bosch Gimpera' with the support of the 'Fundació pel Desenvolupament Sostenible'. M.C. was supported by the Biodiversity Research Institute (IRBio) of the University of Barcelona, and E.E. by grants awarded from the Conservation, Research and Education Opportunities (CREO, 2010) and the National Research Council of Argentina (CONICET). All the IRBio authors are part of the research groups 2009SGR-842 of the 'Generalitat de Catalunya'. Maps created with Maptool (www.seaturtle.org). D.M. and A.F.R. thank the ARCHELON field leaders S. Baker, C. Davy and S. Müller for their help in sample collection. We thank G. Ashcroft for English grammar corrections and H. Vander Zanden and 3 anonymous referees for reviewing the draft manuscript.

\section{LITERATURE CITED}

Arendt MD, Segars AL, Byrd JI, Boynton J, Schwenter JA, Whitaker JD, Parker L (2012) Migration, distribution, and diving behavior of adult male loggerhead sea turtles (Caretta caretta) following dispersal from a major breeding aggregation in the Western North Atlantic. Mar Biol 159:113-125

Bolten AB (2003) Active swimmers-passive drifters: the oceanic juvenile stage of loggerheads in the Atlantic system. In: Bolten AB, Witherington BE (eds) Loggerhead sea turtle. Smithsonian Institution Press, Washington, DC, p 63-78
Bosc E, Bricaud A, Antoine D (2004) Seasonal and interannual variability in algal biomass and primary production in the Mediterranean Sea, as derived from 4 years of SeaWiFS observations. Global Biogeochem Cycles 18: GB1005, doi: 10.1029/2003GB002034

Bowen BW, Bass AL, Soares L, Toonen RJ (2005) Conservation implications of complex population structure: lessons from the loggerhead turtle (Caretta caretta). Mol Ecol 14:2389-2402

> Broderick AC, Glen F, Godley BJ, Hays GC (2003) Variation in reproductive output of marine turtles. J Exp Mar Biol Ecol 288:95-109

Broderick AC, Coyne MS, Fuller WJ, Glen F, Godley BJ (2007) Fidelity and overwintering of sea turtles. Proc R Soc Lond B Biol Sci 274:1533-1538

Cardona L, Revelles M, Parga ML, Tomás J and others (2009) Habitat use by loggerhead sea turtles Caretta caretta off the coast of eastern Spain results in a high vulnerability to neritic fishing gear. Mar Biol 156: 2621-2630

Casale P (2011) Sea turtle by-catch in the Mediterranean. Fish Fish 12:299-316

Casale P, Margaritoulis D (2010) Sea turtles in the Mediterranean: distribution, threats and conservation priorities. IUCN, Gland

Casale P, Abbate G, Freggi D, Conte N, Oliveiro M, Argano $\mathrm{R}$ (2008) Foraging ecology of loggerhead sea turtles Caretta caretta in the central Mediterranean Sea: evidence for a relaxed life history model. Mar Ecol Prog Ser 372:265-276

Ceriani SA, Roth JD, Evans DR, Weishampel JF, Ehrhart LM (2012) Inferring foraging areas of nesting loggerhead turtles using satellite telemetry and stable isotopes. PLoS ONE 7:e45335

Degobbis D, Gilmartin M (1990) Nitrogen, phosphorus, and biogenic silicon budgets for the northern Adriatic Sea. Oceanol Acta 13:31-45

> Drago M, Cardona L, Aguilar A (2010) Diet of lactating South American sea lions, as inferred from stable isotopes, influences pup growth. Mar Mamm Sci 26: 309-323

Dutton PH (1995) Methods for collection and preservation of samples for sea turtle genetic studies. In: Bowen BW, Witzell WN (eds) Proceedings of the International Symposium on Sea Turtle Conservation Genetics. NOAA Tech Memo NMFS-SEFSC 396, National Technical Information Service, Springfield, VA, p 17-24

> Eder E, Ceballos A, Martins S, Pérez-García H, Marín I, Marco A, Cardona L (2012) Foraging dichotomy in loggerhead sea turtles Caretta caretta off northwestern Africa. Mar Ecol Prog Ser 470:113-122

> Fossette S, Girard C, López-Mendilaharsu M, Miller P and others (2010) Atlantic leatherback migratory paths and temporary residence areas. PLoS ONE 5:e13908

> Frankel NS, Vander Zanden HB, Reich KJ, Williams KL, Bjorndal KA (2012) Mother-offspring stable isotope discrimination in loggerhead sea turtles Caretta caretta. Endang Species Res 17:133-138

Frazer NB, Richardson JI (1986) The relationship of clutch size and frequency to body size in loggerhead turtles, Caretta caretta. J Herpetol 20:81-86

Fry B (2006) Stable isotope ecology. Springer, New York, NY > Gaspar P, Benson SR, Dutton PH, Réveillère A and others (2012) Oceanic dispersal of juvenile leatherback turtles: going beyond passive drift modelling. Mar Ecol Prog Ser 
$457: 265-284$

Halama KJ, Reznick DN (2001) Adaptation, optimality, and the meaning of phenotypic variation in natural populations. In: Orzak SH, Sober E (eds) Adaptationism and optimality. Cambridge University Press, Cambridge, p 242-272

Hamad N, Millot C, Taupier-Letage I (2006) The surface circulation in the eastern basin of the Mediterranean Sea. Sci Mar 70:457-503

Hatase H, Takai N, Matsuzawa Y, Sakamoto W and others (2002) Size-related differences in feeding habitat use of adult female loggerhead turtles Caretta caretta around Japan determined by stable isotope analyses and satellite telemetry. Mar Ecol Prog Ser 233:273-281

> Hawkes LA, Broderick AC, Coyne MS, Godfrey MH and others (2006) Phenotypically linked dichotomy in sea turtle foraging requires multiple conservation approaches. Curr Biol 16:990-995

Hawkes LA, Witt MJ, Broderick AC, Cocker JW and others (2011) Home on the range: spatial ecology of loggerhead turtles in Atlantic waters of USA. Divers Distrib 17: 624-640

> Hays GC, Fossette S, Katselidis KA, Mariani P, Schofield G (2010) Ontogenetic development of migration: Lagrangian drift trajectories suggest a new paradigm for sea turtles. J R Soc Interface 7:1319-1327

> Hobson KA (1999) Tracing origins and migration of wildlife using stable isotopes: a review. Oecologia 120:314-326

Hobson KA, Gibbs HL, Gloutney ML (1997) Preservation of blood and tissue samples for stable-carbon and stablenitrogen isotope analysis. Can J Zool 75:1720-1723

Hochscheid S, Saied AM, Oureghi A, Dryag SMH, Bentivegna F (2012) Satellite tracking reveals: loggerhead turtles nesting in Libya prefer to feed on the Tunisian plateau. In: Jones TT, Wallace BP (eds) Proc 31st Annu Symp on Sea Turtle Biology and Conservation. NOAA Tech Memo NMFS-SEFSC-631, NOAA Fisheries Service, Miami, FL, p 138-139

Mansfield KL, Saba VS, Keinath JA, Musick JA (2009) Satellite tracking reveals a dichotomy in migration strategies among juvenile loggerhead turtles in the Northwest Atlantic. Mar Biol 156:2555-2570

Margaritoulis D, Rees A (2011) Loggerhead turtles nesting at Rethymno, Greece, prefer the Aegean Sea as their main foraging area. Mar Turtle Newsl 131:12-14

Margaritoulis D, Argano R, Baran I, Bentivegna F and others (2003) Loggerhead turtles in the Mediterranean Sea: present knowledge and conservation perspectives. In: Bolten AB, Witherington BE (eds) Loggerhead sea turtle. Smithsonian Institution Press, Washington, DC, p 175-198

Martínez del Rio C, Wolf N, Carleton SA, Gannes LZ (2009) Isotopic ecology ten years after a call for more laboratory experiments. Biol Rev Camb Philos Soc 84:91-111

McClellan CM, Read AJ (2007) Complexity and variation in loggerhead sea turtle life history. Biol Lett 3:592-594

McClellan CM, Braun-McNeil J, Avens L, Wallace BP, Read AJ (2010) Stable isotopes confirm a foraging dichotomy in juvenile loggerhead sea turtles. J Exp Mar Biol Ecol $387: 44-51$

Miller JD (1997) Reproduction in sea turtles. In: Lutz PL, Musick JA (eds) The biology of sea turtles. CRC Press, Boca Raton, FL, p 51-81

Millot C, Taupier-Letage I (2004) Circulation in the Mediterranean Sea. The handbook of environmental chemistry,
Vol 1. Springer, Berlin

Oczkowski AJ, Nixon SW, Granger SL, El-Sayed AFM, McKinney RA (2009) Anthropogenic enhancement of Egypt's Mediterranean fishery. Proc Natl Acad Sci USA 106:1364-1367

Pajuelo M, Bjorndal KA, Reich KJ, Arendt MD, Bolten AB (2012) Distribution of foraging habitats of male loggerhead turtles (Caretta caretta) as revealed by stable isotopes and satellite telemetry. Mar Biol 159:1255-1267

> Pantoja S, Repeta DJ, Sachsb JP, Sigman DM (2002) Stable isotope constraints on the nitrogen cycle of the Mediterranean Sea water column. Deep-Sea Res I 49:1609-1621

Patel SH, Panagopoulou A, Morreale SJ, Margaritoulis D, Spotila JR (2012) Post-nesting behavior of loggerheads from Crete revealed by satellite telemetry. In: Jones TT, Wallace PT (eds) Proc 31st Ann Symp on Sea Turtle Biology and Conservation. NOAA Tech Memo NMFSSEFSC-631, NOAA Fisheries Service, Miami, FL, p 168 (Abstract)

Payo-Payo A, Ruiz B, Cardona L, Borrell A (2013) Effect of tissue decomposition on stable isotope signatures of striped dolphins Stenella coeruleoalba and loggerhead sea turtles Caretta caretta. Aquat Biol 18:141-147

Plot V, Jenkins T, Robin JP, Fossette S, Georges JY (2013) Leatherback turtles are capital breeders: morphometric and physiological evidence from longitudinal monitoring. Physiol Biochem Zool 86:385-397

Plotkin P (2003) Adult migrations and habitat use. In: Lutz PL, Musick JA, Wyneken J (eds) The biology of sea turtles, Vol 2. CRC Press, Boca Raton, FL, p 225-241

> Putman NF, Naro-Maciel E (2013) Finding the 'lost years' in green turtles: insights from ocean circulation models and genetic analysis. Proc R Soc Lond B Biol Sci 280: 20131468

Putman NF, Scott R, Verley P, Marsh R, Hays GC (2012) Natal site and offshore swimming influence fitness and long-distance ocean transport in young sea turtles. Mar Biol 159:2117-2126

Pyke GH (1984) Optimal foraging theory: a critical review. Annu Rev Ecol Syst 15:523-575

> Reich KJ, Bjorndal KA, Frick MJ, Witherington BE, Johnson C, Bolten AB (2010) Polymodal foraging in adult female loggerheads (Caretta caretta). Mar Biol 157:113-121

Robinson AR, Leslie WG, Theocharis A, Lascaratois A (2001) Ocean circulation currents: Mediterranean sea circulation. In: Turekian KK, Thorpe SA (eds) Encylopedia of ocean sciences. Academic Press, London, p 1689-1703

> Schofield G, Hobson VJ, Fossette S, Lilley MKS, Katselidis KA, Hays GC (2010) Fidelity to foraging sites, consistency of migration routes and habitat modulation of home range by sea turtles. Divers Distrib 16:840-853

Sella I (1982) Sea turtles in the eastern Mediterranean and northern Red Sea. In: Bjorndal K (ed) Biology and conservation of sea turtles. Smithsonian Institute Press, Washington, DC, p 417-423

> Shillinger GL, Palacios DM, Bailey H, Bograd SJ and others (2008) Persistent leatherback turtle migrations present opportunities for conservation. PLoS Biol 6:e171

Stephens DW, Krebs JR (1986) Foraging theory. Princeton University Press, Princeton, NJ

Tomás J, Aznar FJ, Raga A (2001) Feeding ecology of the loggerhead turtle Caretta caretta in the western Mediterranean. J Zool 255:525-532

Travaglini A, Bentivegna F (2011) The grey swimming crab Liocarcinus vernalis (Risso, 1816): a new important prey 
of loggerhead sea turtles Caretta caretta in the central Tyrrhenian Sea. In: Bentivegna F, Maffucci F, Mauriello V (eds) 4th Mediterranean Conference of Marine Turtles, 7-10 Nov 2011, Naples. Milagro, Naples, p 18 (Abstract)

Vander Zanden MJ, Rasmussen JB (2001) Variation in $\delta^{15} \mathrm{~N}$ and $\delta^{13} \mathrm{C}$ trophic fractionation: implications for aquatic food web studies. Limnol Oceanogr 46:2061-2066

Vander Zanden HB, Bjorndal KA, Reich KJ, Bolten AB (2010) Individual specialists in a generalist population: results from a long-term stable isotope series. Biol Lett 6: 711-714

Voss M, Baker A, Bange HW, Conley D and others (2011) Nitrogen processes in coastal and marine ecosystems. In: Sutton MA, Howard CM, Ersiman JW (eds) The European nitrogen assessment: sources, effects and policy perspectives. Cambridge University Press, Cambridge, p $147-176$

Editorial responsibility: Scott Shaffer, San Jose, California, USA
Wallace BP, Heppell SS, Lewison RL, Kelez S, Crowder LB (2008) Impacts of fisheries bycatch on loggerhead turtles worldwide inferred from reproductive value analyses. J Appl Ecol 45:1076-1085

Wallace BP, Kot CY, DiMatteo AD, Lee T, Crowder LB, Lewison RL (2013) Impacts of fisheries bycatch on marine turtle populations worldwide: toward conservation and research priorities. Ecosphere 4:art40

Wyneken J, Madrak SV, Salmon M, Foote J (2008) Migratory activity by hatchling loggerhead sea turtles (Caretta caretta L.): evidence for divergence between nesting groups. Mar Biol 156:171-178

Zbinden JA, Bearhop S, Bradshaw P, Gill B, Margaritoulis D, Newton J, Godley BJ (2011) Migratory dichotomy and associated phenotypic variation in marine turtles revealed by satellite tracking and stable isotope analysis. Mar Ecol Prog Ser 421:291-302

Submitted: May 30, 2013; Accepted: October 11, 2013 Proofs received from author(s): January 18, 2014 